\title{
Efektifitas Metode William's Flexion dan Yoga Terhadap Intensitas Nyeri Punggung Bawah pada Ibu Hamil Trimester III di Kota Tanjungpinang Tahun 2019
}

\author{
Rahmadona, Kartika Sri Dewi Batubara
}

\begin{abstract}
Abstrak
Nyeri punggung bawah pada kehamilan merupakan nyeri pada area lumbosacral. Hal ini sangat mengganggu aktivitas harian ibu hamil yang apabila tidak ditangani dapat menyebabkan kualitas hidup ibu hamil menjadi buruk. Beberapa terapi non farmakologis seperti latihan William's flexion dan yoga dapat diupayakan mengatasi keluhan nyeri punggung bawah pada kehamilan.Tujuan: Menentukan efektifitas metode William's flexion dan yoga terhadap intensitas nyeri punggung bawah pada ibu hamil trimester III di Kota Tanjungpinang tahun 2019. Metode: Penelitian ini adalah pra eksperimen dengan two group pre test post test design terhadap 60 sampel yang terbagi dua kelompok yaitu kelompok William's flexion dan yoga. Data dikumpulkan dari Agustus hingga Oktober 2019, kemudian diukur menggunakan skala ukur numerik. Analisis data menggunakan t-test dependent dan independent. Hasil: Penelitian menunjukkan uji rerata dalam tiap kelompok perlakuan menunjukkan hasil bermakna $(p=0,000)$ dengan selisih rerata penurunan intensitas nyeri punggung bawah pada kelompok William's flexion sebesar 1,27 dan kelompok yoga sebesar 2,50. Uji rerata antar kelompok perlakuan juga menunjukan hasil bermakna $(p=0,000)$. Simpulan: Metode William's flexion dan yoga efektif menurunkan intensitas nyeri punggung bawah. Latihan yoga memberi penurunan intensitas nyeri lebih besar daripada latihan William's flexion sehingga kedua metode ini bisa dipakai untuk mengatasi keluhan nyeri punggung bawah pada ibu hamil trimester III.
\end{abstract}

Kata kunci: nyeri punggung bawah, William's flexion, yoga

\begin{abstract}
Lower back pain in pregnancy is a pain in the lumbosacral area. This significantly interferes with pregnant women's daily activities, and if it is not treated, it can lead to a low quality of life. Objectives: To determined the effectiveness of the William's flexion and yoga methods on the intensity of low back pain in the third trimester pregnant in Tanjungpinang city in 2019. Methods:This study was a quasi-experiment study with two groups of pre-test post-test design on 60 samples divided into 2 groups, William's Flexion and Yoga groups. Data were collected from August to October 2019 and were measured using a Numeric Rating Scale (NRS). Data were analyzed using dependent samples $t$-test and independent samples t-test. Results: The average test in each treatment group showed significant results $(p=0.000)$. The difference in the average reduction in low back pain intensity in William's flexion group of 1.27 and the yoga group of 2.50. The mean test between treatment groups also showed significant results $(p=0.000)$. Conclusion: The method of William's flexion and yoga are equally effective in reducing the intensity of low back pain. The yoga practice provides a more significant reduction in pain intensity than William's Flexion exercise. These two methods can be used to treat complaints of low back pain in third-trimester pregnant women.
\end{abstract}

Keywords: low back pain, William's flexion, yoga

Affiliasi penulis: Jurusan Kebdanan Poltekkes Kemenkes Tanjungpinang,
Korespondensi: Rahmadona, Email : rahmadona@poltekkes-

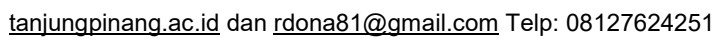




\section{PENDAHULUAN}

Nyeri punggung bawah (low back pain) pada kehamilan merupakan nyeri yang terjadi pada area lumbosakral. Nyeri punggung biasanya akan meningkat intensitasnya seiring pertambahan usia kehamilan karena nyeri ini merupakan akibat pergeseran pusat gravitasi dan postur tubuh. ${ }^{1}$ Nyeri punggung bawah bersifat intermitten dan diperparah oleh aktivitas dengan posisi yang sama dalam waktu yang lama, biasanya terjadi dalam waktu 30 menit seperti berjalan, duduk, berdiri. ${ }^{2}$

Gejala nyeri punggung ini juga disebabkan oleh peningkatan hormon estrogen dan progesteron yang berpengaruh pada sendi, ikatan tulang dan otot dipinggul sehingga panggul berotasi ke depan dan mengubah postur tubuh menjadi hiperlordosis. Postur hiperlordosis ini menambah ketegangan pada pelvis dan lumbar bawah sehingga menyebabkan nyeri punggung bawah. ${ }^{3,4,5}$

Sebuah survey tahun 2014 menyatakan bahwa $70 \%$ dari total 157 ibu hamil mengalami nyeri punggung bawah. ${ }^{6}$

Beberapa penelitian di Indonesia juga menunjukkan hal serupa yakni $47 \%$ dari 180 ibu hamil yang diteliti mengalami nyeri punggung bawah. ${ }^{7}$ Penelitian Mafikasari dan Kartikasari (2015) yang melaporkan $80 \%$ ibu hamil mengalami nyeri punggung bawah. $^{8}$

Nyeri punggung bawah bisa sangat mengganggu aktivitas harian ibu hamil dan apabila tidak ditangani dapat menyebabkan kualitas hidup ibu hamil menjadi buruk. Masalah ini akan berlanjut dalam bentuk cidera kambuhan atau muncul terus menerus dengan kondisi lebih buruk sesuai dengan perjalanan usia kehamilannya. $^{9}$

Ada beberapa cara untuk mengurangi keluhan nyeri punggung bawah antara lain dengan terapi farmakologis dan nonfarmakologis. Pengendalian nyeri secara farmakologis memang lebih efektif dibandingkan dengan metode nonfarmakologi, namun demikian terapi farmakologis lebih mahal dan berpotensi mempunyai efek samping. Dalam kehamilan, metode farmakologis juga mempunyai pengaruh bagi ibu, janin, maupun bagi kemajuan persalinan. ${ }^{5}$
Terapi non farmakologis bisa dipilih untuk mengatasi keluhan nyeri punggung bawah pada ibu hamil salah satunya dengan melakukan exercise atau latihan relaksasi. Exercise efektif mencegah keluhan nyeri punggung bawah pada kehamilan, mengurangi intensitas nyerinya dan kemungkinan disability. ${ }^{10,11}$

Penelitian yang dilakukan oleh Shiri et al (2017) menunjukkan bahwa latihan selama proses kehamilan bisa menurunkan nyeri dan direkomendasikan pada ibu hamil. ${ }^{12}$ Selama kehamilan, latihan ringan sampai sedang aman diberikan kepada ibu hamil. Latihan yang bisa diberikan yaitu latihan-latihan dengan gerakan streching yang aman bagi ibu hamil seperti latihan William's flexion dan yoga. Kedua jenis excersice ini termasuk terapi non farmakologis yang dapat mengurangi intensitas nyeri punggung bawah dan mengurangi rasa ketidaknyamanan akibat perubahan fisiologis pada kehamilan. ${ }^{13}$

Latihan William's flexion juga dapat mengurangi tekanan pada bagian posterior dan lumbal serta mengembalikan gerakan dan kekuatan pada punggung bawah yang membantu menurunkan dan mencegah kembalinya nyeri punggung bawah. ${ }^{14}$ Gerakan pada latihan William's flexion merupakan gerakan streching meliputi pelvic tilting, single knee to chest, double knee to chest dan wall squat. Gerakan ini menurut Elkheshen et al (2016) signifikan dalam menurunkan nyeri punggung bawah pada ibu hamil. ${ }^{15}$

Yoga yang dilakukan saat hamil (prenatal yoga) adalah modifikasi dari gerakan-gerakan yoga yang disesuaikan dengan kondisi ibu hamil dan bertujuan untuk mempersiapkan ibu hamil secara fisik, mental dan spiritual untuk proses persalinan. ${ }^{16}$ Yoga dalam kehamilan menggabungkan postur khusus dan teknik yang bermanfaat bagi ibu hamil dan membantu menghilangkan ketidaknyamanan yang disebabkan perubahan tubuh selama kehamilan. Terlebih lagi, yoga yang dilakukan ibu hamil dapat membuat tubuh lebih lentur, nyaman, menunjang sirkulasi darah, mengatasi sakit punggung, pinggang, pegal dan bengkak. $^{2}$ Yoga yang dilakukan pada trimester III kehamilan dapat mengurangi keluhan nyeri punggung bawah yang umum dialami ibu hamil. ${ }^{17}$

Berdasarkan uraian latar belakang tersebut, perlu dilakukan penelitian "Efektivitas metode William's 
flexion dan yoga terhadap intensitas nyeri punggung bawah pada ibu hamil trimester III di Kota Tanjungpinang Tahun 2019"

\section{METODE}

Penelitian ini menggunakan metode quasi eksperimen dengan rancangan two groups pretest posttest design yang bertujuan untuk mengetahui efektivitas metode William's flexion dan yoga terhadap intensitas nyeri punggung bawah pada ibu hamil trimester III. Pengumpulan data dilakukan pada bulan Agustus hingga Oktober 2019 di kelas-kelas ibu hamil yang tersebar di Kota Tanjungpinang.

Populasi penelitian adalah semua ibu hamil trimester III dengan keluhan nyeri punggung bawah yang datang ke kelas ibu hamil di Kota Tanjungpinang. Sampel penelitian dimbil secara purposive sampling dengan pertimbangan tertentu secara sengaja untuk memenuhi tujuan penelitian. ${ }^{18,19,20}$

Pertimbangan tersebut mengacu pada kriteria inklusi yaitu ibu hamil trimester III, kehamilan normal dan sehat, memiliki keluhan nyeri punggung bawah dan bersedia menjadi responden. Kriteria ekslusinya adalah ibu hamil trimester III dengan penyakit penyerta, memiliki riwayat perdarahan dan sedang menderita plasenta previa. Berdasarkan pertimbangan tersebut,maka jumlah sampel ditetapkan 30 untuk masing-masing kelompok perlakuan sehinga total sampel menjadi 60 orang ibu hamil trimester III.

Instrumen yang digunakan dalam penelitian ini adalah kuisioner pengukuran nyeri obyektif yaitu skala intensitas nyeri numeric (Numeric Rating Scale). Pengukuran nyeri punggung bawah dilakukan dua kali yaitu sebelum (pre-test) dan sesudah (post-test) setelah masing-masing kelompok baik William's flexion dan yoga diberikan latihan sebanyak dua kali seminggu selama tiga minggu.

Data yang telah dikumpulkan diuji dengan dependen samples t-test untuk mengetahui rerata penurunan nilai intensitas neyri punggung bawah ibu hamil pada masing-masing kelompok perlakuan sebelum dan sesudah perlakuan. Beda rerata penurunan antar kelompok perlakuan di uji dengan menggunakan independent samples t-test dengan derajat kemaknaan untuksetiap uji adalah $95 \%$.
Penelitian ini dilakukan setelah mendapat persetujuan etik nomor LB.02.03/6/31/2019 dari Komisi etik penelitian Poltekkes Kemenkes Riau.

\section{HASIL}

Pengambilan data penelitian ini telah dilaksanakan mulai bulan Agustus hingga Oktober 2019 terhadap 60 orang ibu hamil trimester III yang terbagi menjadi 2 kelompok yaitu kelompok latihan William's flexion dan kelompok latihan yoga. Data dianalisis untuk mengetahui penurunan intensitas nyeri punggung bawah sebelum dan sesudah perlakuan diberikan pada masing-masing kelompok. Perolehan data kemudian diolah dan diuji secara univariat maupun bivariat sehingga diperoleh hasil sebagai berikut.

Tabel 1. Karakteristik subyek penelitian

\begin{tabular}{lrc}
\hline \multicolumn{1}{c}{ Karakteristik } & $\mathbf{f}$ & $\%$ \\
\hline Umur & 3 & 5 \\
$<20$ tahun & 51 & 85 \\
20- 35 tahun & 6 & 10 \\
$\quad>35$ tahun & & \\
\hline Usia kehamilan & 13 & 21.7 \\
28 - 31 minggu & 20 & 33.3 \\
32 - 35 minggu & 27 & 45 \\
$>35$ minggu & & \\
\hline Paritas & 29 & 48.3 \\
Paritas 1 & 27 & 45 \\
Paritas 2-3 & 4 & 6.7 \\
Paritas >3 & &
\end{tabular}

Keterangan $: f=$ frekuensi, $\%=$ persentase

Sumber: Data primer, 2019

Tabel 1 menunjukkan bahwa dari 60 ibu hamil yang diteliti, mayoritas responden berada di rentang umur 20-35 tahun (85\%), dengan usia kehamilan lebih banyak 35 minggu keatas (45\%) menjelang hamil aterm dan lebih banyak sedang hamil anak pertama $(48.3 \%)$

Uji beda rerata dalam kelompok perlakuan william's flexion dan kelompok perlakuan yoga, dilakukan terlebih dahulu uji normalitas data menggunakan uji One Samples Kolmogorov- Smirnov Test dengan hasil nilai $\mathrm{p}=0,267(\mathrm{P}>0.05)$ yang berarti data terdistribusi normal dan uji homogenitas varian dengan menggunakan uji One way ANOVA dengan 
hasil nilai $p=0,770(p>0,05)$ untuk kelompok sebelum perlakuan dan nilai $p=0,568(p>0,05)$ untuk kelompok setelah perlakuan. Hal ini menunjukkan varians dari masing-masing kelompok William's flexion dan yoga adalah sama (homogen).

Berdasarkan hasil uji normalitas dan homogenitas varian data, maka uji hipotesis yang akan digunakan adalah dependent samples t-test untuk uji beda dalam kelompok dan uji independent samples t-test untuk uji beda antar kelompok seperti yang terlihat dalam tabel berikut ini.

Tabel 2. Analisis uji beda rerata penurunan intensitas nyeri punggung bawah dalam kelompok perlakuan

\begin{tabular}{ccccccc}
\hline & & WF & & \multicolumn{3}{c}{ YG } \\
\hline & Pre & Post & $\begin{array}{c}\text { Pre- } \\
\text { Post }\end{array}$ & Pre & Post & $\begin{array}{c}\text { Pre- } \\
\text { Post }\end{array}$ \\
& & & & & \\
\hline rerata & 4.13 & 2.87 & 1.27 & 4.97 & 2.47 & 2.50 \\
& & & & & & \\
\hline SD & 1.961 & 1.776 & 0.185 & 2.008 & 1.548 & 0.460 \\
& & & & & & \\
\hline $\mathrm{p}$ & & 0.000 & & & 0.000 &
\end{tabular}

Keterangan: $\mathrm{WF}=$ william's flexion, $\mathrm{YG}=$ yoga

Sumber: Data primer, 2019

Tabel 2 memperlihatkan bahwa rerata intensitas nyeri punggung bawah sebelum perlakuan latihan William's flexion adalah 4.13 dengan standar deviasi 1.961, setelah perlakuan rerata nyeri menjadi 2.87 dengan standar deviasi 1.776 dimana rerata selisih 1.27. Pada kelompok perlakuan yoga, rerata intensitas nyeri sebelum perlakuan adalah 4.97 dengan standar deviasi 2.008 dan setelah perlakuan menjadi 2.47 dengan standar deviasi 1.548 dan rerata selisih 2.50 .

Hasil uji dependent samples t-test pada Tabel 2 menunjukkan nilai $p=0,000 \quad(p<0,05)$ yang dapat diartikan bahwa ada hubungan yang bermakna antara latihan william's flexion dengan penurunan intensitas nyeri punggung bawah pada ibu hamil trimester III atau dengan kata lain latihan william's flexion efektif menurunkan nyeri punggung bawah pada ibu hamil trimester III.

Pada kelompok perlakuan yoga, berdasarkan hasil uji dependent samples t-test seperti yang terlihat di Tabel 2 juga menunjukkan hubungan yang bermakna antara latihan yoga terhadap intensitas nyeri punggung bawah pada ibu hamil trimester III dimana nilai $p$ yang diperoleh adalah $0,000(p<0,05)$ sehingga disimpulkan latihan yoga juga efektif menurunkan intensitas nyeri punggung bawah pada ibu hamil trimester III.

Pengukuran beda rerata nyeri punggung bawah pada ihu hamil trimester III antar kelompok perlakuan william's flexion dan kelompok yoga dilakukan dengan uji independent samples t-test menghasilkan nilai sebagai berikut.

Tabel 3. Analisis uji beda rerata penurunan intensitas nyeri punggung bawah antar kelompok perlakuan

\begin{tabular}{|c|c|c|c|c|c|}
\hline Kelompok & & & & & \\
\hline Perlakuan & $\mathrm{n}$ & Rerata & SD & SE & $\mathbf{p}$ \\
\hline WF & 30 & 1.27 & 0.740 & 0.135 & \multirow{2}{*}{0.000} \\
\hline YG & 30 & 2.50 & 1.106 & 0.202 & \\
\hline
\end{tabular}

Data pada Tabel 3 menunjukkan bahwa rerata penurunan intensitas nyeri punggung bawah pada kelompok William's flexion adalah 1.27 dengan standar deviasi sebesar 0.740 dan pada kelompok yoga adalah penurunan intensitas nyerinya 2.50 dengan standar deviasi sebesar 1.106. Hasil uji beda rata-rata antar dua kelompok tersebut menghasilkan nilai p $0,000(<0,005)$. Hal ini menunjukkan ada perbedaan bermakna terhadap rerata penurunan intensitas nyeri punggung bawah antara kelompok William's flexion dan kelompok yoga.

\section{PEMBAHASAN}

Berdasarkan hasil penelitian, terbukti bahwa metode latihan william's flexion efektif menurunkan intensitas nyeri punggung bawah pada ibu hamil trimester III $(p=0,000)$ dengan selisih rerata penurunan sebesar 1.27. Begitu juga dengan metode latihan yoga dengan nilai $p=0,000$ efetif untuk menurunkan intensitas nyeri punggung bawah pada ibu hamil trimester III dengan selisih rerata penurunan sebesar 2.50. Secara umum kedua metode ini dapat digunakan untuk menurunkan intensitas nyeri punggung bawah pada kehamilan trimester III.

Nyeri punggung bawah pada kehamilan terutamanya disebabkan karena pertambahan ukuran rahim karena pertumbuhan janin dan perubahan postur tubuh untuk menopang pembesaran rahim 
tersebut. Akibatnya, pusat gravitasi ibu berpindah ke depan, pelvis berotasi ke depan dan tulang lumbal melengkung berlebihan (hiperlordosis). Kondisi ini menambah ketegangan pada daerah lumbal dan otototot punggung bawah dan menimbulkan rasa nyeri dan meningkatkan rasa ketidaknyaman ibu hamil hingga menganggu aktivitas harian. ${ }^{1,3}$ Pada penelitian ini, seluruh sampel penelitian mengeluhkan nyeri punggung bawah bervariasi dari keluhan nyeri ringan hingga nyeri berat. Untuk mengurangi keluhan tersebut latihan william's flexion dan yoga dapat dipilih sebagai terapi non farmakologis dan aman diterapkan pada ibu hamil. ${ }^{13}$

Hasil penelitian ini sesuai dengan penelitian oleh Ricci tahun 2011 bahwa latihan William's flexion dapat mengurangi tekanan pada bagian posterior dan lumbal serta mengembalikan gerakan dan kekuatan pada punggung bawah yang membantu menurunkan dan mencegah kembalinya nyeri punggung bawah. ${ }^{14}$ Begitu juga dengan penelitian di Bengkulu yang membuktikan bahwa latihan peregangan william's flexion memiliki pengaruh yang signifikan terhadap penurunan skala nyeri pada penderita nyeri punggung bawah di Poli syaraf RSUD Bengkulu $(p=0,000){ }^{21}$ Penelitian kombinasi lumbar flexion exercise dan diaphragm breathing exercise oleh Khaerunnisa tahun 2018 juga membuktikan bahwa kombinasi kedua latihan tersebut berpengaruh signifikan terhadap penurunan nyeri punggung bawah. ${ }^{22}$ Penelitian oleh Dachlan LM tahun 2009 membuktikan bahwa latihan back exercise model william's flexion di Surakarta berpengaruh terhadap pengurangan nyeri punggung bawah. $^{23}$

Gerakan pada latihan william;s flexion atau lumbar flexion excercise merupakan gerakan peregangan (streching) meliputi pelvic tilting, single knee to chest, double knee to chest dan wall squat. Gearakan-gerakan ini menurut Elkheshen tahun 2016 signifikan dalam menurunkan nyeri punggung bawah pada ibu hamil. ${ }^{15}$

Saat otot-otot lumbal mengalami ketegangan terutama yang terjadi pada kehamilan trimester III, sarkomer otot akan terus menerima impuls dan berkontraksi hingga memendek. Saat dilakukan gerakan William's flexion tarikan yang dialami otot lumbal akan memanjang dan berelaksasi dan ketegangan otot berkurang dan akhirnya menurunkan nyeri yang dirasakan pada punggung bawah. ${ }^{24,25}$

Latihan Yoga juga terbukti mampu menurunkan intensitas nyeri punggung bawah pada ibu hamil trimester III. Hal ini sejalan dengan penelitian Mediarti et al tahun 2014 yang membuktikan bahwa yoga yang dilakukan pada trimester III kehamilan dapat mengurangi keluhan nyeri punggung bawah pada ibu hamil. ${ }^{17}$ Begitu juga dengan penelitian Fitriani tahun 2018 di Polewali Mandar yang membuktikan bahwa yoga berpengaruh terhadap penurunan nyeri punggung bawah pada ibu hamil. ${ }^{27}$

Penelitian Martin dan Silva tahun 2014 yang membandingkan metode yoga dan orientasi postural juga membuktikan bahwa yoga lebih efektif dari orientasi postural dalam mengurangi intensitas nyeri lumbopelvic pada kehamilan. ${ }^{5}$ Yoga direkomendasikan sebagai terapi non-farmakologik untuk mengurangi nyeri punggung bawah pada kehamilan. ${ }^{11}$

Yoga merupakan bagian dari terapi non farmakologis yang dapat menurunkan nyeri. ${ }^{26}$ Yoga merupakan upaya praktis dalam menyelaraskan tubuh, pikiran dan jiwa dan bermanfaat membentuk postur tubuh yang tegap, membina otot yang lentur dan kuat, memurnikan syraf pusat yang terdapat di tulang punggung. ${ }^{17}$ Yoga yang dilakukan saat hamil (prenatal yoga) adalah modifikasi dari gerakangerakan yoga yang disesuaikan dengan kondisi ibu hamil dan bertujuan untuk mempersiapkan ibu hamil secara fisik, mental dan spiritual untuk proses persalinan. $^{16}$

Yoga dalam kehamilan menggabungkan postur khusus dan teknik yang bermanfaat bagi ibu hamil dan membantu menghilangkan ketidaknyamanan yang disebabkan perubahan tubuh selama kehamilan. Terlebih lagi, yoga yang dilakukan ibu hamil dapat membuat tubuh lebih lentur, nyaman, menunjang sirkulasi darah, mengatasi sakit punggung, pinggang, pegal dan bengkak ${ }^{2,16,26}$

Gerakan-gerakan dalam yoga mampu melenturkan otot punggung, memperlancar peredaran darah tubuh, dan menambah kesadaran klien sehingga dapat dengan mudah merespon terjadinya nyeri dalam tubuh. Pose-pose dalam gerakan yoga juga dapat merangsang otot punggung untuk memanjang sehingga memblokade timbulnya nyeri di 
bagian punggung dan peredaran darah yang lancar mampu merangsang otak mengeluarkan obat anti nyeri secara fisiologis. ${ }^{2,16,26}$

Hasil analisis beda rerata antar kelompok William's flexion dan yoga diperoleh nilai $p=0,000$ $(p<0,005)$. Hal ini membuktikan bahwa ada perbedaan yang bermakna terhadap penurunan intensitas nyeri punggung bawah antara kelompok latihan menggunakan metode William's flexion dan kelompok Lathan yoga. Berdasarkan selisih rerata penurunan intensitas nyeri punggung bawah pada kelompok William's flexion dan kelompok yoga, selisih 1,27 diperoleh pada kelompok william's flexion sebelum dan sesudah perlakuan dan selisih 2,50 diperoleh pada kelompok yoga sebelum dan sesudah perlakuan

Hal ini menunjukkan bahwa latihan yoga memberi pengaruh lebih besar terhadap penurunan intensitas nyeri punggung bawah atau dengan kata lain latihan yoga lebih efektif dibandingkan latihan william's flexion dalam menurunkan intensitas nyeri punggung bawah pada ibu hamil trimester III.

\section{SIMPULAN}

Metode latihan William's flexion efektif menurunkan intensitas nyeri punggung bawah pada ibu hamil trimester III.

Metode latihan yoga efektif menurunkan intensitas nyeri punggung bawah pada ibu hamil trimester III.

Ada selisih rerata penurunan intensitas nyeri punggung bawah antara metode latihan william's flexion dan latihan yoga sebelum dan sesudah perlakuan.

Ada perbedaan bermakna terhadap penurunan intensitas nyeri punggung bawah pada ibu hamil trimester III antar kelompok William's flexion dan kelompok yoga.

Kedua metode latihan efektif menurunkan intensitas nyeri punggung bawah pada ibu hamil trimester III dan dapat digunakan sebagai alternatif terapi non farmakologis terhadap keluhan nyeri punggung bawah dalam kehamilan.

\section{UCAPAN TERIMA KASIH}

Terimakasih kepada Poltekkes Kemenkes Tanjungpinang yang telah mendukung penelitian ini. Terimakasih juga disampaikan pada Dinas Kesehatan Kota Tanjungpinang, pengelola kelas- kelas ibu hamil di Kota Tanjungpinang, ibu-ibu hamil trimester III serta enumerator penelitian atas kontribusinya terhadap pelaksanaan penelitian ini

\section{DAFTAR PUSTAKA}

1. Varney H. Buku ajar asuhan kebidanan. Edisi ke-4. Renata Komalasari, penterjemah. Jakarta: EGC; 2014.

2. Vermani E, Mittal R, Weeks A. Pelvic girdle pain and low back pain in pregnancy: A review. Pain Practice. 2010;10(1):60-71.

3. Casagrande JD, Gugala Z, Clark SM, Lindsey R. Low back pain and pelvic girdle pain in pregnancy. The journal of American Academy of Orthopaedic Surgeon. 2015; 23(9):539-49.

4. Cunningham FG, et al. Williams obstetric. 23rd edition. New York: Mc GrawHill; 2013.

5. Martin RF, Silva JL. Treatment of pregnancyrelated lumbar and pelvic girdle pain by the yoga method: A randomized controlled study. The Journal of Alternative and Complementary Medicine. 2014; 20(1):24-31.

6. Sinclair M, Close C, Hughes C, McCullough J and Lidle D. How do woman manage pregnancyrelated low back pain and/or pelvic pain? Descriptive findings from a online survey. The Royal College of Midwives. Evidence Based Midwifery. 2014;12(3):76-82.

7. Hakiki IN. Efektifitas Terapi air hangat terhadap nyeri tulang belakang pada ibu hamil di wilayah kerja Puskesmas Pisangan [skripsi]. Jakarta: Prodi IImu Keperawatan UIN Syarif Hidayatullah; 2015.

8. Mafikasari A, Kartikasari R I. Posisi tidur dengan kejadian back pain (nyeri punggung) pada ibu hamil trimester III. Jurnal Kebidanan. 2015;7(2):2634.

9. Katonis PA, Kampouroglou A, Aggelopoulos A Kakavelakis K, Lykoudis S, Makrigiannakis A, et al. Pregnancy- Related Low Back Pain.Hippokratia. 2011;15(3):205-10 
10. Liddle SD, Pennick V. Intervention for preventing and treating low back pain and pelvic pain during pregnancy. Cochrane Database of Systematic Review. 2015. Issue 9. Art No. CD001139.(diunduh 14 Juli 2019) Tersedia dari: https://www. cochranelibrary.com/cdsr/doi/10.1002/14651858.C D001139.pub4

11. Kinser PA, Pauli J, Jallo N, Shall M, Kars K, Hoekstra M, et al. Physical activity and yoga-based approaches for pregnancy low back pain and pelvic pain. Journal of Obstetric, Gynecologic \& Neonatal Nursing. 2017;46(3):334-46.

12. Shiri R, Coggon D and Falah-Hasani K. Exercise for preventing of low back and pelvic girdle pain in pregnancy: A meta analysis of randomized controlled trials. European Journal of Pain. 2018; 22(1):19-27.

13. Hinman SK, Smith KB, Quillen DM, Smith MS. Exercise in pregnancy: A clinical review. Sport Health: A Multidisiplinary Approach. 2015; 7 (6): 527-31.

14. Ricci B, Marchetti M, Figura F. Biomechanics of sit ups exercise. Medsci Sports Exercise. 2011;13(1): 54-9.

15. Elkheshen SA, Mohammed HS, Abdelgawad HA. The effect of practicing pelvic rocking on lowering dissability level through decreasing pregnancy related lower back pain. Journal of American Science. 2016;12(5):98-103.

16. Pratignyo T. Yoga ibu hamil plus postnatal yoga. Jakarta: Pustaka Bunda;2014.

17. Mediarti D, Sulaiman S, Rosnani, Jawiah J. Pengaruh yoga antenatal terhadap pengurangan keluhan ibu hamil trimester III. Jurnal Kedokteran dan Kesehatan. 2014;1(1):47-53.

18. Sugiyono. Metode penelitian kuantitatif kualitatif dan R\&D. Bandung: Afabeta; 2012.
19. Dahlan MS. Besar Sampel dan cara pengambilan sampel dalam penelitian kedokteran dan kesehatan. Edisi ke-2. Jakarta: Salemba Medika; 2009.

20. Dharma K. Metodogi penelitian keperawatan. panduan melaksanakan dan menerapkan hasil penelitian. Jakarta: Trans Info Media; 2011.

21. Sari $F$, Hermansyah $H$. Latihan peregangan pada penderita nyeri punggung bawah. 2018 Juni. (diunduh 14 Juli 2019). Tersedia dari: https://doi.org/10.33088/jmk. v11i1.356.

22. Khaerunnisa H. Pengaruh kombinasi lumbar flexion exercise dan diaphragm breathing exercise terhadap perubahan nyeri punggung bawah pada ibu hamil di Puskesmas Sinoa Bantaeng [skripsi]. Makassar: Progran Studi Fisioterapi, Fakultas Keperawatan, Universitas Hasanuddin; 2018.

23. Dachlan LM. Pengaruh back excersice pada nyeri punggung bawah [tesis]. Surakarta: Magister Kedokteran Keluarga, Universitas Sebelas Maret; 2009.

24. Kolar P, Sulc J, Kyncl M, Sanda J, Cakrt O, Andel R. Postural function of the diaphragm in person with and without chronic low back pain. Journal of Orthopaedics Sports Physical therapy. 2012;42(4): 352-62.

25. Page $P$. Current consept in muscle strecthing for exercise and rehabilitation. International Journal Sport Physical Therapy. 2012;7(1). 109-19.

26. Sindhu P. Yoga untuk kehamilan sehat, bahagia, dan penuh makna. Edisi Bugar. Bandung: Qonita Mizan Pustaka; 2009.

27. Fitriani L. Efektivitas senam hamil dan yoga hamil terhadap penurunan nyeri punggung bawah pada ibu hamil trimester III di Puskesmas Pekkabata. JKesmas. 2018;4(2):72-80. 